\title{
PENGEMBANGAN KERANGKA MANAJEMEN RISIKO PADA PERBANKAN SYARIAH
}

\author{
Diah Novianti \\ IAIN Syaikh Abdurrahman Siddik Bangka Belitung \\ Email: noviantidiah91@gmail.com
}

\begin{abstract}
Islamic banking such as the other business institution will face different kind of risk that inherent on its main business activity. In business, risk defined as a posibillity an can appear every time, before, when, and after the decision making. Islamic banking faced different risk with the conventional banking, because its uniquenes. Thus, the development of risk management framework in Islamic banking is very important to do, especially in frame of risk identification, measuring, mitigation and monitoring. This paper will discuss about risk management in Islamic Banking, in theoretically and the implementation of risk management. The scope of this study will include the identification of risk in Islamic Banking, stage of risk management in Islamic Banking, risk management model, and also the devolpment of risk management framework in Islamic Banking.
\end{abstract}

Keywords: risk, risk management, Islamic Banking.

\begin{abstract}
Abstrak
Perbankan syariah seperti umumnya lembaga bisnis akan menghadapi bermacam-macam risiko yang melekat pada aktivitas bisnisnya. Risiko di dalam bisnis merupakan suatu kepastian dan bisa muncul kapan saja, sebelum, ketika, bahkan ketika pengambilan keputusan dilakukan. Risiko yang dihadapi oleh bank syariah berbeda dengan risiko yang dihadapi oleh bank konvensional, karena adanya keunikan yang tidak ada pada bank konvensional. Oleh karenanya pengembangan kerangka manajemen risiko pada perbankan syariah sangat penting dilakukan, khususnya dalam rangka identifikasi, pengukuran, mitigasi serta monitoring risiko. Tulisan ini akan membahas tentang manajemen risiko di perbankan syariah, baik secara teori maupun praktek. Ruang lingkup pembahasan akan mencakup jenis-jenis risiko yang dihadapi perbankan syariah, tahapan manajemen risiko perbankan syariah, model manajemen risiko perbankan syariah serta pengembangan kerangka manajemen risiko perbankan syariah.
\end{abstract}

Kata kunci: risiko, manajemen risiko, perbankan syariah. 


\section{A. PENDAHULUAN}

Perbankan syariah adalah salah satu instrumen bisnis dalam keuangan syariah. Salah satu karakteristik khas dari suatu bisnis yaitu adanya risiko dan return. Risiko bisa muncul kapan saja yakni sebelum, ketika, bahkan setelah pengambilan keputusan dilakukan. Seringkali risiko muncul karena adanya lebih dari satu pilihan, dan dampak dari tiap pilihan tersebut belum dapat diketahui dengan pasti, sebagaimana tidakpastinya masa depan. Hal ini menyebabkan akan selalu ada opportunity cost dalam setiap keputusan yang diambil.

Bank Syariah, jika dicermati, merupakan salah satu bisnis yang sarat risiko. Hal ini dikarenakan, dalam menjalankkan aktivitasnya bank banyak berhubungan dengan produk-produk yang mengandung risiko, seperti mudharabah ${ }^{1}$. Hal ini mencerminkan beberapa risiko pada bank Syariah bersifat unik dan lebih beragam dibanding yang dihadapi oleh bank Konvensional. Bank Syariah tidak hanya dihadapkan oleh risiko-risiko tradisional, seperti risiko kredit, tapi juga dihadapkan pada risiko yang muncul karena keunikan karakteristik bisnis dan akadnya. Risiko-risiko unik dan khas dalam bank Syariah antara lain risiko kepatuhan syariah, risiko pembiayaan, risiko imbal hasil, risiko investasi dan sebagainya.

Risiko dalam konteks perbankan mencerminkan kejadian yang mungkin terjadi. Disadari atau tidak kejadian-kejadian tersebut dapat diantisipasi, sebab risiko berpotensi menimbulkan kerugian pendapatan dan modal pada Bank. Akan tetapi karena merupakan suatu hal yang pasti dalam proses bisnis, risiko tidak dapat dihindari, namun risiko dapat dikelola dan dikontrol. Oleh karenanya, seperti institusi perbankan umum, Bank Syariah juga perlu untuk merumuskan prosedur dan metodologi mengernai

${ }^{1}$ Muhammad, Manajemen Bank Syariah, Yogyakarta: Unit Penerbit dan Percetakan, 2011, hlm. 
manajemen risiko yang di dalamnya mencakup identifikasi, pengukuran, pengawasan dan pengelolaan risiko yang mungkin timbul dalam aktivitas bisnis.

\section{B. DEFINISI MANAJEMEN RISIKO}

Risiko dapat didefinisikan sebagai konsekuensi atas pilihan yang mengandung ketidakpastian yang berpotensi mengakibatkan hasil yang tidak diharapkan atau dampak negatif lainnya yang merugikan pengambil keputusan. Dari definisi tersebut risiko mengandung beberapa dimensi, yakni biaya peluang, potensi kerugian, ketidakpastian, dan diperolehnya hasil yang tidak sesuai harapan. Dengan berbagai dimensi inilah risiko diukur, dimitagasi, dan dimonitor selama proses bisnis berlajan. ${ }^{2}$

Jeroen P.M.M mendefinisikan risiko sebagai "Risk are uncertain future events that could influence the achievemnet of the Bank's objectives, including strategic, operational, financial and compliance objectives". Bentuk-Bentuk kejadian yang tidak terduga tersebut antara lain ${ }^{3}$ :

a. Kegagalan peminjam membayar pinjaman

b. Fluktuasi nilai tukar mata uang

c. Fraud, dokumentasi keamanan yang tidak lengkap, dsb

d. Ketidakpatuhan terhadap prinsip dan hukum syariah

e. Berbagai kejadian lain yang dapat berpengaruh dalam kerugian Bank.

Bisnis perbankan (baik Perbankan Syariah ataupun perbankan Konvensional) tidak terlepas dari proses pengkalkulasian atau perhitungan risiko yang mungkin terjadi. Manajemen Risiko bukan hanya meminimalisasi kerugian tetapi mengoptimalkan risk reward equation. Hal ini $\mathrm{h} \operatorname{lm} 4$.

${ }^{2}$ Imam Wahyudi,dkk, Manajemen Risiko Bank Islam, Penerbit Salemba Empat: Jakarta, 2013, ${ }^{3}$ Jeroen P.M.M.Thijs. Risk Manajement in Islamic Banking. Bank Islam Malaysia Berhad 
berarti keuntungan kompetitif sebuah Bank, tergantung sebaik apa Bank tersebut bisa mengelola risiko.

Manajemen Risiko adalah proses dengan berbagai macam tahapan risiko, seperti identifikasi, pengukuran, mitigasi dan pengontrolan, pelaporan dan monitoring4. Selanjutnya, manajemen resiko ini berfungsi sebagai filter atau pemberi peringatan diri terhadap kegiatan usaha bank. Tujuan dari manajemen resiko itu sendiri untuk: menyediakan informasi tentang resiko kepada pihak regulator; memastikan bank tidak mengalami kerugian yang bersifat unacceptable; meminimalisasi kerugian dari berbagai resiko; mengukur eksposur dan pemusatan risiko serta mengalokasikan modal dan membatasi resiko ${ }^{5}$.

Di sisi lain manajemen risiko diartikan sebagai cara-cara yang digunakan manajemen untuk menangani berbagai permasalahan yang disebabkan oleh adanya risiko, mengidentifikasi manajemen risiko sebagai keseluruhan sistem pengelolaan dan pengendalain risiko yang dihadapai oleh bank yang terdiri dari seperangkat alat, teknik, proses manajemen dan organisasi yang ditujukan untuk memelihara tingkat profitabilitas dan tingkat kesehatan bank yang ditetapkan dalam corporate plan ${ }^{6}$. Berdasarkan pengertian tersebut, dapat disimpulkan bahwa manajemen risiko merupakan sistem yang digunakan untuk mengelola risiko yang dihadapi dan mengendalikan risiko tersebut agar tidak merugikan.

\section{BENTUK-BENTUK RISIKO BANK SYARIAH}

Kesuksesan dalam mengelola risiko dapat dicapai hanya jika pengambil keputusan mengetahui dengan pasti pengertian risiko, termasuk

${ }^{4}$ Jeroen P.M.M.Thijs. Risk Manajement in Islamic.....

5 Adiwarman Karim, Bank Islam Analisis Fiqih dan keuangan, Jakarta: PT Raja Grafindo Persada, 2013, hlm. 255.

${ }^{6}$ Ferry N. Idroes \& Sugiarto,. Manajemen Resiko Perbankan “dalam konteks kesepakatan Basel dan Peraturann Bank Indonesia”, Yogyakarta: Graha Ilmu, 2006, hlm. 7. 
di dalamnya bentuk-bentuk risiko secara umum. Secara umum, risiko dapat digolongkan menjadi 2, yaitu:

a. Berdasarkan faktor penyebab

1) Risiko nonbisnis, muncul dari berbagai faktor yang tidak terkait dengan bisni yang dijalankan, namun dampaknya akan mempengaruhi bisnis, seperti kebakaran dan bencana alam.

2) Risiko bisnis, muncul karena proses bisnis yang dijalankan oleh Bank, seperti kesalahan dalam proses perencanaan.

b. Berdasarkan dampak dan Unit Usaha Syariah.

1) Risiko unik, yaitu risiko yang dampaknya hanya ditanggung oleh proyek atau bank tertentu, terisolasi dan dapat didiversifikasi.

2) Risiko pasar, yaitu risiko yang dampaknya menyebabkan efek domino, dimana faktor risiko ini umumnya terkait dengan variabel makro ekonomi atau kondisi sektoral atau geografis atau indikator pasar lainnya7.

Berdasarkan PBI Nomor 13/23/PBI/2011 tentang Penerapan Manajemen Risko bagi Bank Umum Syariah. Terdapat sepuluh jenis risiko yang dhadapi bank syariah, dimana delapan risiko pertama merupakan risiko umu yang dihadapi oleh bank konvensional, dan dua risiko terakhir merupakan risiko khusus Bank Syariah ${ }^{8}$. Penambahan dua risiko ini sejalan dengan platform manajemen risiko yang dikeluarkan oleh IFSB (Islamic Financial Services Board). Sepuluh risiko tersebut antara lain:

a. Risiko Kredit

Risiko ini muncul sebagai akibat kegagalan atau kelalaian nasabah atau pihak lain dalam memenuhi kewajibannya (liabilitas) kepada bank atau sering juga disbut dengan risiko gagal bayar. Salah satu jenis risiko

\footnotetext{
${ }^{7}$ Imam Wahyudi,dkk, Manajemen Risiko ..................., hlm.5

${ }^{8}$ Imam Wahyudi,dkk, Manajemen Risiko ...................., hlm. 25
} 
kredit adalah risiko konsentrasi pembiayaan, yang timbul akibat terkonsentrasinya pendanaan kepada satu atau sekelompok pihak.

b. Risiko pasar

Risiko ini muncul akbat adanya pergerakan harga pasar (adverse movement) dari portofolio aset yang dimiliki oleh Bank dan berpotensi merugikan bank. Jenis-jenis risiko pasar antara lain risiko nilai tukar, risiko komoditas, risiko jatuh tempo dan risiko suku bunga.

c. Risiko likuiditas

Risiko likuiditas terjadi akibat ketidakmampuan Bank Syariah dalam memenuhi liabilitas yang jatuh tempo. Risiko ini muncul sebagai akibat dari ketidaksamaan waktu jatuh tempo antara sumber pendanaan (DPK) dan akad pembiayaan bank kepada debitur.

d. Risiko operasional

Risiko operasional adalah risiko kerugian yang diakibatkan oleh pengendalian internal yang kurang memadai, kegagalan proses internal, kegagalan sistem dan sebagainya. Termasuk ke dalam jenis risiko operasional antara lain risiko kepatuhan (compliance risk) dan risiko bisnis.

e. Risiko hukum

Muncul akibat adanya runtutan hukum dan/atau kelemahan aspek hukum.

f. Risiko reputasi

Terjadi akibat menurunnya tingkat kepercayaan stakeholder yang bersumber pada persepsi negatif terhadap bank, seperti dalam hal pelayanan, manajemen, dan ketaatan pada aturan Syariah.

g. Risiko strategis 
Terjadi akibat ketidaktepatan dalam pengambilan dan/atau pelaksanaan suatu keputusan strategis termasuk kegagalan dalam mengantisipasi perubahan lingkungan bisnis.

h. Risiko kepatuhan

Muncul akibat bank tidak mematuhi dan/atau tidak melaksanakan peraturan undang-undang yang berlaku termasuk di dalamnya tidak mengikuti prinsip dan aturan syariah.

i. Risiko imbal hasil

Risiko ini terjadi akibat perubahan tingkat imbal hasil yang dibayarkan bank kepada nasabah dan juga mempenngaruhi perilaku nasabah.

j. Risiko investasi

Risiko ini muncul akibat bank ikut menanggung kerugian usaha debitur yang dibiayai dalam pembiayaan berbasis profit and loss sharing $(\mathrm{PLS})^{9}$.

Tabel 1. Kategori Risiko pada Bank Syariah dan Konvensional

\begin{tabular}{|l|c|c|}
\hline \multicolumn{1}{|c|}{ Tipe Risiko } & $\begin{array}{c}\text { Bank } \\
\text { Konvensional }\end{array}$ & Bank Syariah \\
\hline Risiko Pembiayaan & $\sqrt{ }$ & $\sqrt{ }$ \\
\hline Risiko Investasi & $\mathrm{x}$ & $\sqrt{ }$ \\
\hline Risiko pasar & $\sqrt{ }$ \\
\hline Risiko Likuiditas & $\sqrt{ }$ & $\sqrt{ }$ \\
\hline Risiko Imbal Hasil & $\mathrm{x}$ & $\sqrt{ }$ \\
\hline Risiko Operasional & $\sqrt{ }$ & $\sqrt{ }$ \\
\hline Risiko tidak taat & $\mathrm{x}$ & \\
\hline
\end{tabular}

${ }^{9}$ Peraturan Bank Indonesia Nomor 13/23/PBI 2011 tentang Penerapan Manajemen Risiko bagi Bank Umum Syariah dan Unit Usaha Syariah. Bab I Pasal 1 ayat 7-16 


\begin{tabular}{|l|c|c|}
\hline Syariah & & \\
\hline Risiko Strategis & $\sqrt{ }$ & $\sqrt{ }$ \\
\hline Risiko Hukum & $\sqrt{ }$ & $\sqrt{ }$ \\
\hline Risiko Kepatuhan & $\sqrt{ }$ & $\mathrm{x}$ \\
\hline Risiko tingkat bunga & $\sqrt{ }$ & \\
\hline
\end{tabular}

\section{TAHAPAN MANAJEMEN RESIKO}

Manajemen risiko layaknya sebuah proses yang akan selalu menyertai dalam proses Bank Syariah itu sendiri. Seperti umumnya sebuah proses, manajemen risiko memiliki berbagai tahapan yang saling berkaitan dan berulang untuk saling melengkapi dan menyempurnakan. Manajemen risiko bertujuan untuk memastikan bahwa seluruh kebijakan risiko dan bisnis bisa diimplementasikan secara konsisten.

Pada dasarnya praktik manajemen terbagi dua yakni praktik manajemen risiko klasik dan praktik manajemen risiko modern. Praktik manajemen risiko klasik hanya berorientasi pada pada penetapan batasan risiko yang konsisten dengan tetap berorientasi pada profit. Sementara praktik manajemen modern tidak hanya mengenai penetapan batasan risiko, namun juga menggunakan berbagai ukuran risiko dalam penentuan batasan risiko dan menjalankan risk-adjusted performance pada setiap lininya ${ }^{10}$.

Karakteristik manajemen risiko di Perbankan Syariah berbeda dengan perbankan konvensional, terutama jika dilihat dari beberapa karakteristik unik yang berlandaskan ketundukan Syariah (sharia-compliant). Singkatnya, perbedaan dasar antara perbankan Syariah dengan perbankan Konvensional dalam hal manajemen risiko tidak terletak pada "bagaimana" tapi dalam hal "apa" yang akan diukur"11.

\footnotetext{
${ }^{10}$ Imam Wahyudi,dkk, Manajemen Risiko hlm. 59

${ }^{11}$ Adiwarman Karim, Bank Islam ....., hlm. 256.
} 
Adapun tahapan-tahapan dalam proses manajemen risiko antaralain $^{12}$ :

a. Identifikasi Risiko

Identifikasi risiko adalah proses untuk menentukan risiko apa yang apa yang terjadi, mengapa risiko itu terjadi dan bagaimana risiko itu bisa terjadi. Beberapa tahapan dalam identifikasi risiko yaitu:

1) Menyusun daftar risiko secara komperehesif, berdasarkan dampak pada setiap elemen kegiatan. Proses ini memperlihatkan kemungkinan masalah yang dihadapi dan besarnya kerugian yang mungkin terjadi. Dimana besarnya kerugian akan mempengaruhi level risiko yang akan dihadapi.

2) Menganalisis karakter risiko yang melekat pada Bank Syariah, termasuk risiko yang melekat pada produk dan kegaiatan usaha bank.

3) Menggambarkan proses terjadinya risiko dan menganalisis faktorfaktor penyebab risiko, termasuk menentukan probabilitas risiko.

4) Membuat daftar sumber terjadinya risiko untuk masing-masing risiko.

Tabel 2. Daftar Sumber Terjadinya Risiko

\begin{tabular}{|c|c|c|}
\hline No & Jenis Risiko & Sumber Risiko \\
\hline 1. & Risiko Pembiayaan & $\begin{array}{l}\text { Akun piutang, sewa dan pembiayaan, } \\
\text { transaksi pembiayaan modal kerja, } \\
\text { intrumen ekuitas yang tidak } \\
\text { diperdagangkan, sertifikat investasi } \\
\text { (sukuk),kinerja nasabah pembiayaan, } \\
\text { target NPF, eksekusi jaminan, jenis } \\
\text { pembiayaan, kualitas pembiayaan, limit }\end{array}$ \\
\hline
\end{tabular}

${ }^{12}$ Imam Wahyudi,dkk, Manajemen Risiko hlm. 66-68 


\begin{tabular}{|c|c|c|}
\hline No & Jenis Risiko & Sumber Risiko \\
\hline & & $\begin{array}{l}\text { pembiayaan, dan jatuh tempo } \\
\text { pembiayaan. }\end{array}$ \\
\hline 2. & Risiko Investasi & $\begin{array}{l}\text { Akad investasi mudharabah dan } \\
\text { musyarakah, kegiat usaha dan } \\
\text { operasionalnya. }\end{array}$ \\
\hline 3. & Risiko pasar & $\begin{array}{l}\text { Pergerakan harta dari surat-surat } \\
\text { berharga dan instrumen yang bisa } \\
\text { didagangkan (sukuk), investasi dalam } \\
\text { aset yang disewakan, off-balance sheet } \\
\text { individual portofolio, harga komoditas } \\
\text { dari aset salam, nilai pasar dari sukuk, } \\
\text { nilai pasar dari aset murabahah, dan } \\
\text { foreign exchange. }\end{array}$ \\
\hline 4. & Risiko Likuid & $\begin{array}{l}\text { Arus kas, tipe dana berasal dari } \\
\text { pemegang akun lancar, dan pemegang } \\
\text { akun investasi tidak terikat. }\end{array}$ \\
\hline 5. & Risiko Imbal Hasil & $\begin{array}{l}\text { Perubahan pada imbal hasil acuan yang } \\
\text { terjadi di pasar. }\end{array}$ \\
\hline 6. & Risiko Operasional & $\begin{array}{l}\text { Proses, orang, sistem, tidak patuh } \\
\text { syariah, dan liabilitas fidusia. }\end{array}$ \\
\hline 7. & $\begin{array}{l}\text { Risiko tidak taat } \\
\text { Syariah }\end{array}$ & Ketidaktaatan pada aturan syariah \\
\hline 8. & Risiko Strategis & $\begin{array}{l}\text { Perubahan dalam pasar, kondisi } \\
\text { ekonomi, regulasi, demografis dan } \\
\text { dampaknya pada bisnis, dan dampak } \\
\text { inovasi produk. }\end{array}$ \\
\hline 9. & Risiko Hukum & Proses terjadinya akad, implementasi \\
\hline
\end{tabular}




\begin{tabular}{|l|l|l|}
\hline No & \multicolumn{1}{|c|}{ Jenis Risiko } & \multicolumn{1}{|c|}{ Sumber Risiko } \\
\hline & & regulasi. \\
\hline 10. & Risiko Kepatuhan & $\begin{array}{l}\text { Dampak variasi akad yang digunakan } \\
\text { dalam transaksi, fungsi keberadaan } \\
\end{array}$ \\
& & DPS. \\
\hline
\end{tabular}

Sumber: Dikompilasi dari berbagai sumber

5) Menentukan instrumen yang tepat dalam mengidentifikasi risiko, seperti pengalaman, pencatatan atas risiko yang telah terjadi, dan sebagainya.

Identifikasi risiko, khususnya untuk menilai nasabah, dapat diidentifikasi dengan metode credit scoring, menghitung probabilitas gagal bayar, kerugian ketika gagal bayar terjadi, rencana bisnis, dan arus kas terkait bagaimana nasabah membayar kembali kewajibannya. Selain itu, tujuan manajemen risiko dalam bank Syariah adalah untuk mencapai profitiabilitas dan stabilitas dalam bidang keuangan. Untuk memenuhi tujuan ini, identifikasi dan pengukuran dari sisi keuangan bisa dilihat dari laporan keuangan bank, misalnya:

Tabel 3. Identifikasi dan Pengukuran dari Sisi Keuangan ${ }^{13}$ :

\begin{tabular}{|l|l|}
\hline \multicolumn{1}{|c|}{ Tujuan Finansial } & \multicolumn{1}{|c|}{ Hal yang Diukur } \\
\hline Meningkatkan aset & Total aset \\
\hline Mengurangi liabilitas & $\begin{array}{l}\text { Total liabilitas } \\
\text { aset }\end{array}$ \\
\hline Imbal hasil pada aset (ROA) & $\begin{array}{l}\text { Rasio laba neto terhadap } \\
\text { ekuitas }\end{array}$ \\
\hline Imbal hasil pada ekuitas (ROE \\
\hline Perputaran aset & Rasio pendapatan terhadap \\
aset \\
\hline
\end{tabular}

${ }^{13}$ Imam Wahyudi,dkk, Manajemen Risiko hlm. 66-68 


\begin{tabular}{|l|l|}
\hline \multicolumn{1}{|c|}{ Tujuan Finansial } & \multicolumn{1}{c|}{ Hal yang Diukur } \\
\hline Menjaga financial leverage & Rasio aset terhadap modal \\
\hline Menjaga likuiditas & $\begin{array}{l}\text { Rasio aset lancar terhadap } \\
\text { utang lancar }\end{array}$ \\
\hline
\end{tabular}

b. Pengukuran Risiko

Setelah proses identifikasi, risiko perlu diukur secara konsisten serta disajikan dalam bentuk yang mudah dipahami. Pengukuran risiko secara garis besar terbagi dua, yaitu mendeskripsikan dan menguantifikasi risiko. Kegiatan tersebut dilakukan menggunakan probabilitas (pembentukan matriks rasio) serta mengestimasi tingkat signifikansi risiko, batas toleransi bank terhadap risiko, dan analisis biaya-manfaat.

Proses identifikasi risiko di bank syariah berbeda dengan bank konvensional karena setiap kontrak/akad yang dilakukan dalam perbankan syariah mempunyai risiko yang berbeda satu sama lain. Dalam perbankan konvensional, hampir seluruh aset berasal dari hutang $(d e b t)$, sedangkan aset dalam perbankan syariah berasal dari kegiatan pendanaan (trade financing) sampai kegiatan kerjasama (equity partnership). Hal ini menyebabkan perbankan syariah mempunyai risiko unik yang berbeda dengan perbankan konvensional, sehingga proses identifikasi atau pengukuran risiko bank syariah berbeda dengan bank konvensional. Perbedaan tersebut antara lain:

1) aset yang berasal dari akad pembiayaan tidak sepenuhnya merupakan aset finansialdan menanggung risiko lain disamping risiko pembiayaan dan risiko pasar;

2) aset non finansial seperti real estate, komoditas, serta kontrak ijarah istisnah mempunyai karakteristik risiko yang unik; 
3) perbankan syariah menggunakan skema kerjasama serta aset profit and loss sharing yang mempunyai profil risiko yang lebih tinggi

4) perbankan syariah belum mempunyai instrumen yang jelas dalam mitigasi dan hedging risiko, seperti instrumen derivativ, yang meningkatkan risiko aset keseluruhan dari pada yang dihadapi oleh bank konvensional ${ }^{14}$.

Salah satu bentuk kuantifikasi risiko adalah dengan menggunakan matriks risiko. Matriks risiko digunakan untuk mengidentifikasi risiko, menghitung probablitas keterjadian dan pengaruh keterjadian tersebut, kemudian memeringkat risiko berdasarkan preferensi risiko yang dipilih oleh bank.

c. Mitigasi Risiko

Mitigasi risiko sebenarnya merupakan tahapan akhir dari beberapa proses manajemen risiko sebelumnya, yaitu identifikasi risiko, analisis risiko, dan evaluasi risiko. Setelah melalui ketiga tahapan tersebut, bank dapat melakukan prioritas risiko dengan memilih beberapa risiko yang berpengaruh secara signifikan terhadap bank. Risiko yang diprioritaskan oleh bank akan dimitigasi lebih lanjut dan dipantau implementasinya. Jadi, mitigasi risiko berfungsi untuk menetralisasi, meminimalisasi, atau bahkan menghilangkan dampak negatif yang muncul dari kejadian di suatu kategori risiko.

Mitigasi risiko dalam perbankan syariah bertujuan untuk ${ }^{15}$ :

1) Pencegahan. Perbankan syariah memerlukan persetujuan dari Dewan Pengawas Syariah untuk mencegah terjadinya ketidaktundukan syariah dalam proses transaksi perbankan. $\operatorname{hlm} 27$.

${ }^{14}$ Mohamed Helmy ,Risk Management in Islamic Banks, MPRA Paper No. 38706, May 2012 , ${ }^{15}$ Adiwarman Karim, Bank Islam Analisis. hlm. 252-253. 
2) Penyelidikan. Pengawasan dalam perbankan Islam meliputi dua aspek, yaitu pengawasan dari Bank Indonesia dan pengawasan dari aspek Syariah oleh Dewan Pengawas Syariah.

3) Pengkoreksian. Pengkoreksian atas kesalahan yang terjadi harus melibatkan Bank Indonesia jika berkaitan dengan aspek perbankan, atau Dewan Syariah Nasional jika berhubungan dengan aspek Syariah.

\section{d. Monitoring Risiko}

Proses monitoring risiko adalah proses pemantauan yang dilakukan oleh bank berdasarkan tingkat risiko aktual yang terjadi pada bank. Tingkat risiko aktual ini dibandingkan dan dimonitoring dengan berbagai ketentuan risiko yang telah ditetapkan sebelumnya, seperti risk tolerance level, risk limit, dan lain sebagainya. Ketika terjadi ketidakcocokan antara kondisi aktual dan kebijakan risiko bisa berarti dua hal. Pertama, terjadinya pelanggaran terhadap kebijakan manajemen risiko. Kedua, kebijakan risiko yang ditetapkan sudah tidak lagi relevan sehingga harus dilakukan revisi dan penyesuaian terhadap situasi masa kini.

Monitoring risiko dalam perbankan Syariah tidak hanya mencakup sisi manajemen Bank Syariah, namun juga meliputi pengawasan dari DPS.

Tabel 4. Status dan Kondisi Pengawasan Risiko ${ }^{16}$

\begin{tabular}{|c|c|c|c|}
\hline & Frekuensi & Konten & Contoh \\
\hline DPS & Tiap semester & Rangkuman & Laporan secara \\
& & transaksi & singkat \\
& & syariah & \\
\hline
\end{tabular}

${ }^{16}$ Adiwarman Karim, Islamic Banking: .,hlm. 253. 


\begin{tabular}{|c|c|c|c|}
\hline $\begin{array}{c}\text { Board level E risk } \\
\text { management } \\
\text { committee }\end{array}$ & Tiap tahun & Rangkuman & $\begin{array}{c}\text { Pemetaan risiko- } \\
\text { penjelasan } \\
\text { secara singkat }\end{array}$ \\
\hline $\begin{array}{c}\text { Middle } \\
\text { Management }\end{array}$ & Tiap kuarter & $\begin{array}{c}\text { Rangkuman + } \\
\text { penjelasan }\end{array}$ & $\begin{array}{c}\text { Kuadran- } \\
\text { operational Risk } \\
\text { Management } \\
\text { Plan (OMRP) }\end{array}$ \\
\hline Day to day & Tiap bulan & Detail & Frekuensi risiko \\
\hline
\end{tabular}

e. Pengendalian dan Pelaporan Risiko

Tahapan terakhir adalah pengendalian dan pelaporan risiko. Pada tahap ini, pengawasan atas keseluruhan proses dan tahapan ini dilakukan secara berkesinambungan dan terdokumntasi. Hal ini menandakan proses manajemen risiko telah dilakukan sepenuhnya.

\section{E. MODEL MANAJEMEN RISIKO DI BANK SYARIAH}

Praktik manajemen risiko di setiap bank sangat tergantung dari karakteristik bisnis bank tersebut. Demikian pula Bank Syariah, praktik manajemen risiko pada Bank Syariah tidak dapat disamakan dengan Bank Konvensional. Perbedaan tersebut khususnya terlihat dalam tataran filosofis, mitigasi, dan kebijakan risiko karena adanya perbedaan prinsip bisnis yang mendasari keduanya. Sehingga, proses awal manajemen risiko selalu dimulai dari analisis terhadap proses bisnis dan penentuan konteks di mana manajemen risiko akan diterapkan.

Manajemen risiko yang baik adalah manajemen yang bisa menciptakan nilai tambah bagi bank. Hal tersebut tidak dapat terjadi jika manajemen risiko bukan merupakan bagian integral dari bank tersebut. Manajemen risiko yang baik seharusnya dapat berjalan secara dinamis, interaktif, dan 
responsif terhadap setiap perubahan yang terjadi di lingkungan internal maupun eksternal bank.

Proses manajemen risiko pada bank Syariah dapat diawali dengan penentuan konteks. Tahap penetuan konteks ini bertujuan untuk memperoleh gambaran menyeluruh atas parameter dasar, ruang lingkup, dan kerangka kerja manajemen risiko, mengindentifikasi lingkungan penerapan manajemen risiko, mengetahui dan menetapkan para pemangku kepentingan utama, dan menetapkan kriteria untuk menganalisis dan mengevaluasi risiko.

Salah satu cakupan dalam tahap penetapan konteks adalah ditetapkannya risk appetite bank terhadap risiko ${ }^{17}$. Risk appetite adalah tingkat toleransi manajemen bank dalam menciptakan nilai bagi pemilik bank. Risk appetite terdiri dari dua komponen, yaitu risk tolerance dan risk limit. Risk tolerance menggambarkan tingkat risiko yang masih dapat diterima oleh bank secara keseluruhan karena dianggap potensi kerugian yang akan terjadi masih dapat diserap oleh cadangan modal yang dimiliki. Sedangkan risk limit merupakan panduan bagi setiap unit bisnis yang ada pada struktur organisasi bank syariah untuk mengambil risiko pada setiap transaksi yang dilakukan.

Dua hal yang selalu menjadi pertimbangan dalam penentuan risk appetite adalah tingkat risk dan return yang ada pada setiap transaksi dalam perbankan. Risk-return merupakan hal yang selalu melekat pada bisnis, maka tingkat penerimaan atau sikap manajemen terhadap risiko tidak boleh mengabaikan return yang ada pada setiap aktivitas bisnis. Hal ini dapat diilustrasikan oleh gambar di bawah ini:

${ }^{17}$ Imam Wahyudi,dkk, Manajemen Risiko hlm. 62 . 
Gambar 1. Ilustrasi risk-return trade-off

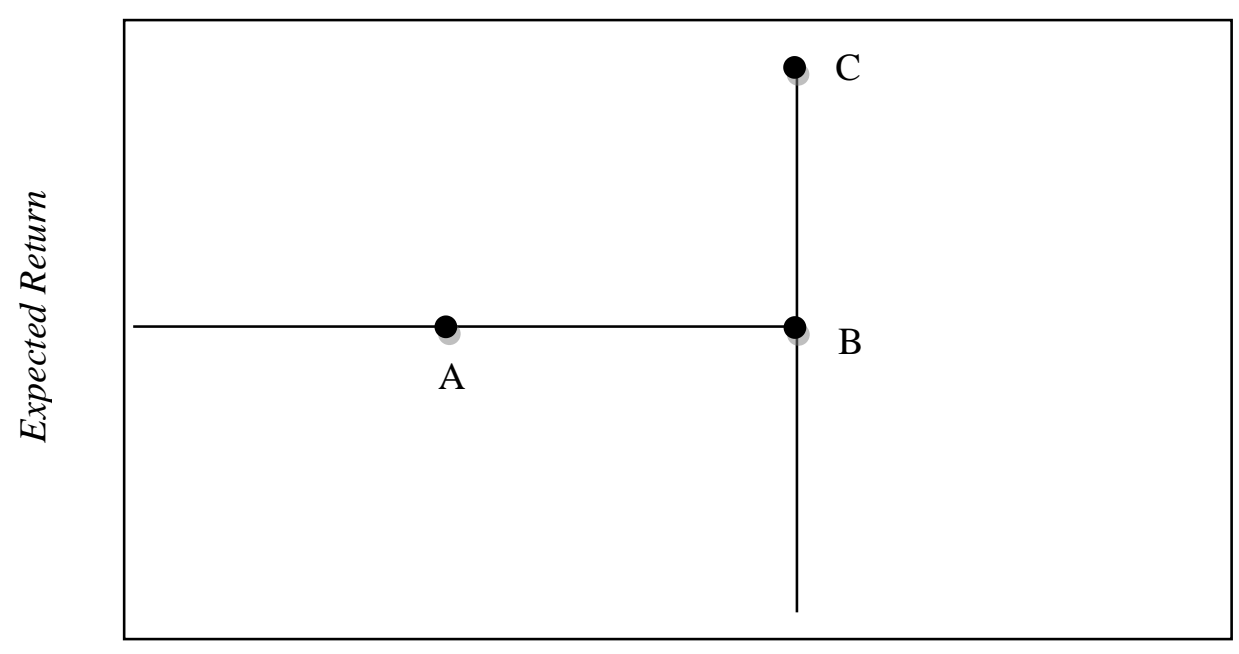

Risk/Standard Deviation

Setelah diidentifikasi, langkah selanjutnya adalah menilai risiko-risiko yang ada untuk mengetahui tingkat keparahan kerugian yang akan diakibatkan dan tingkat kemungkinan keterjadian risiko tersebut. Hasil dari penilaian risikko tersebut akan berguna untuk melakukan prioritisasi risiko bank yang nantinya dimitigasi. Umumnya, metodologi yang digunakan dalam penilaian risiko adalah composite risk index (CRI) yang dihitung dengan:

$\mathrm{CRI}=$ dampak kejadian risiko $\mathrm{x}$ probabilitas kejadian

Dampak kejadian risiko dinilai dengan skala 1-5, dimana 1 mewakili minimum dan 5 mewakili maksimum dampak kerugian yang mungkin terjadi (skala mata uang). Sementara probabilitas kerterjadian juga dinilai sama 1-5, dimana 1 mewakili probabilitas rendah dan 5 mewakili probabilitas tinggi. Sehingga CRI akan bernilai 1-25 dan dibagi menjadi 3 kelompok interval, yaitu interval 1-8 (rendah), 9-16 (sedang), dan 7-25 (tinggi). 


\section{F. KERANGKA KERJA MANAJEMEN RISIKO}

Kompleksnya risiko yang dihadapi oleh Bank Syariah mensyaratkan manajemen risiko yang komperehensif, termasuk pelaporan risiko yang komprehensif dan kerangka pengontrolan risiko yang komprehensif pula ${ }^{18}$. Sebuah survei yang dilakukan untuk mengetahui persepsi Institusi Perbankan Syariah terhadap perbedaan jenis risiko untuk tipe pembiayaan berbeda. Hasil dari penelitian menunjukkan bahwa persepsi yang tinggi pada risiko juga menjadi indikasi dari tingkat yang rendah dalam manajemen risiko ${ }^{19}$.

Hal ini juga menandakan ketiadaan pengontrolan risiko melalui kontrol dan proses internal, khususnya pada risiko operasional. Persepsi dari praktisi perbankan syariah atas beberapa isu penting terkait risiko di perbankan syariah masih mengindikasikan bahwa masih terdapat kekurangan dalam hal pemahaman atas risiko-risiko terkait model pembiayaan syariah. Masing-masing model pembiayaan berbasis syariah mempunyai besaran risiko yang berbeda, tergantung pada jenis kontrak pembiayaan tersebut. Model pendanaan musyarakah, istisna, ba'i as salam, dan diminishing musyarakah mempunyai rata-rata risiko yang lebih besar dibanding model pembiayaan yang lain sedangkan kontrak berbasis pembiayaan seperti murabahah dipandang mempunyai risiko yang lebih rendah dibanding yang lain.

Tabel 4. Persepsi Risiko: Risiko di model pembiayaan yang berbeda ${ }^{20}$

\begin{tabular}{|c|c|c|c|c|}
\hline Instrument & $\begin{array}{c}\text { Credit } \\
\text { risk }\end{array}$ & $\begin{array}{c}\text { Mark- } \\
\text { up risk }\end{array}$ & $\begin{array}{c}\text { Liquidity } \\
\text { risk }\end{array}$ & $\begin{array}{c}\text { Operational } \\
\text { risk }\end{array}$ \\
\hline Murabahah & 2.56 & 2.87 & 2.67 & 2.93 \\
\hline
\end{tabular}

${ }^{18}$ Zamir Iqbal dan Abbas Mirakhor, An Introduction to Islamic Finance Theory and Practice, John Wiley \& Sons (Asia): Singapore, 2007, hlm. 246.

19 Tariqullah Khan dan Habib Ahmed, Risk Manajement an Analysis of Issues in Islamic Financial Industry. Occasional Paper No.9, Islamic Development Bank : Jeddah, 2001, hlm. 64.

${ }^{20}$ Tariqullah Khan dan Habib Ahmed, Risk Manajement an Analysis .................. hlm. 64. 


\begin{tabular}{|c|c|c|c|c|}
\hline Instrument & $\begin{array}{c}\text { Credit } \\
\text { risk }\end{array}$ & $\begin{array}{c}\text { Mark- } \\
\text { up risk }\end{array}$ & $\begin{array}{c}\text { Liquidity } \\
\text { risk }\end{array}$ & $\begin{array}{c}\text { Operational } \\
\text { risk }\end{array}$ \\
\hline Mudarabah & 3.25 & 3.00 & 2.46 & 3.08 \\
\hline Musharakah & 3.69 & 3.40 & 2.92 & 3.18 \\
\hline Ijarah & 2.64 & 3.92 & 3.10 & 2.90 \\
\hline Istisna & 3.13 & 3.57 & 3.00 & 3.29 \\
\hline Ba'i al Salam & 3.20 & 3.50 & 3.20 & 3.25 \\
\hline Diminishing Musyarakah & 3.33 & 3.40 & 3.33 & 3.40 \\
\hline
\end{tabular}

Proses manajemen risiko yang tepat di perbankan syariah memerlukan kajian yang khusus, karena keunikan yang ada pada bank syariah dan permasalahan yang di hadapi oleh bank syariah lebih kompleks dibanding bank konvensional. Hal ini diperlukan karena penerapan manajemen risiko yang tepat dapat meningkatkan shareholder value, memberikan pengelola bank gambaran mengenai kemungkinan risiko kerugian di masa depan, meningkatkan metode dan proses pengambilan keputusan yang sistematis berdasarkan ketersediaan informasi kinerja bank serta menciptakan infrastruktur manajemen risiko yang kokoh dalam rangka meningkatkan daya saing di tengah hegemoni perbankan konvensional21.

Hal inilah yang menyebabkan perlunya pengembangan kerangka kerja manajemen risiko, dimana pengukuran, pelaporan, manajemen, kontrol risiko dapat dicakup secara komprehensif. Kerangka kerja manajemen risiko yang baik selalu dimulai dari pemberian mandat dan komitmen kepada salah satu unit dalam struktur organisasi bank. Unit inilah yang bertanggungjawab untuk memastikan penerapan manajemen risiko di bank Syariah. Mandat dan komitmen tersebut biasanya tercantum secara jelas dalam dokumen Risk Manajement Charter (RMC). RMC memuat filosofi

${ }^{21}$ Muhammad Iqbal Fasa, Manajemen Resiko Perbankan Syariah di Indonesia, Li Falah: Jurnal Studi Ekonomi dan Bisnis Islam Volume 1, Nomor 2, Desember2016, hlm. 51. 
penerapan manajemen risiko pada bank Islam, struktur organisasi manajemen risiko, wewenang, tanggungjawab, berbagai ketentuan teknis koordinasi manajemen risiko, dan proses evaluasi periodik terhadap paktik manajemen risiko di bank Islam.

\section{Gambar 2. Kerangka Kerja Manajemen Risiko}

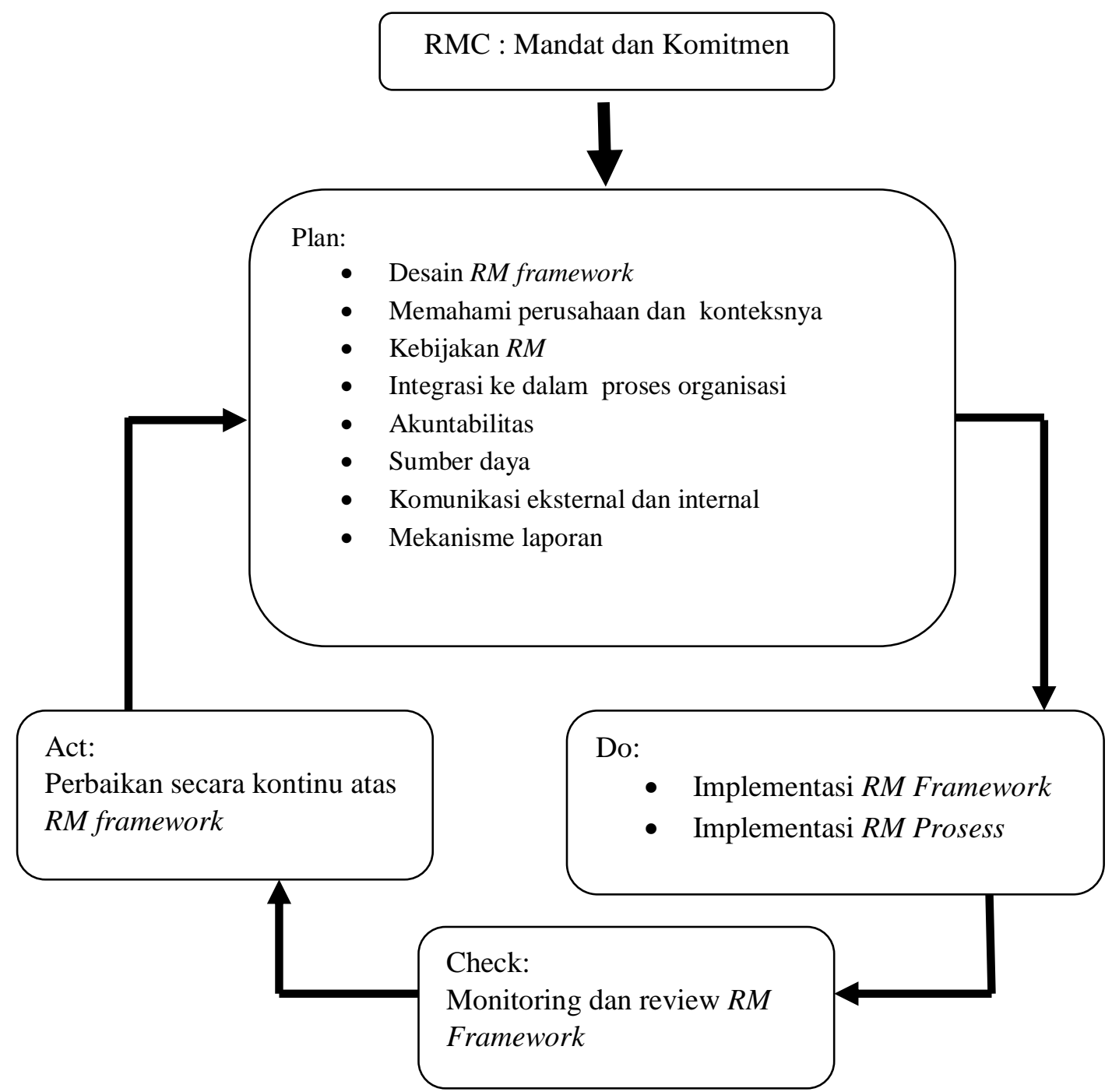




\section{G. PENUTUP}

Manajemen risiko merupakan suatu proses yang berkelanjutan, artinya manajemen risiko tidak hanya berhenti pada satu titik saja. Oleh karenanya, implementasi manajemen risiko tidak mungkin hanya mengandalkan satu atau beberapa orang saja. Manajemen risiko yang baik dalam implementasinya, seharusnya tanggung jawab semua elemen bank secara keseluruhan mengingat tahapan-tahapan risiko merupakan suatu tahapan yang panjang. Selain itu, manajemen risiko pada bank Syariah seharusnya dapat meminimalkan potensi keterjadian dan dampak yang ditimbulkan pada berbagai risiko yang tidak dikehendaki. Pada sisi lain, bank harus siap menerima dan beroperasi dengan risiko tersebut.

Di dalam manajemen risiko tercermin tingkat keberanian sebuah bank dalam mengambil risiko untuk mendapatkan keuntungan. Konsekuensi keberanian bank ini tidak hanya menjadi tanggung jawab divisi manajemen risiko, melainkan tugas dan tanggung jawab bersama semua elemen dalam bank. Karenanya, semua karyawan dari level atas sampai level bawah harus bekerja sama dalam menghadapi risiko yang mungkin terjadi. 


\section{DAFTAR PUSTAKA}

Adiwarman Karim, Bank Islam :Analisis Fiqih dan Keuangan, Jakarta: PT Raja Grafindo Persada, 2013.

Ferry N. Idroes \& Sugiarto,Manajemen Resiko Perbankan "dalam Konteks Kesepakatan Basel dan Peraturann Bank Indonesia", Yogyakarta: Graha Ilmu, 2006.

Imam Wahyudi, dkk., Manajemen Risiko Bank Islam, Penerbit Salemba Empat: Jakarta, 2013.

Jeroen P.M.M.Thijs. Risk Manajement in Islamic Banking. Bank Islam Malaysia Berhad

Muhammad Iqbal Fasa, Manajemen Resiko Perbankan Syariah di Indonesia, Li Falah: Jurnal Studi Ekonomi dan Bisnis Islam Volume 1, Nomor 2, Desember 2016.

Muhammad, Manajemen Bank Syariah, Yogyakarta: Unit Penerbit dan Percetakan, 2011

Peraturan Bank Indonesia Nomor 13/23/PBI 2011 tentang Penerapan Manajemen Risiko bagi Bank Umum Syariah dan Unit Usaha Syariah. Bab I Pasal 1 ayat 7-16

Tariqullah Khan dan Habib Ahmed, Risk Manajement an Analysis of Issues in Islamic Financial Industry, Occasional Paper No.9, Islamic Development Bank : Jeddah, 2001.

Zamir Iqbal dan Abbas Mirakhor, An Introduction to Islamic Finance Theory and Practice, John Wiley \& Sons (Asia): Singapore, 2007. 